www.jmscr.igmpublication.org

Impact Factor 5.84

Index Copernicus Value: 83.27

ISSN (e)-2347-176x ISSN (p) 2455-0450

crossref DOI: _https://dx.doi.org/10.18535/jmscr/v5i3.156

Journal Of Medical Science And Clinical Research

IGM Publication

An official Publication of IGM Publication

\title{
Toxicity impact of Silk dye waste effluent induced Histopathological changes in the Stomach and Intestine of Swiss albino mice Mus musculus and their mitigation using Moringa oleifera leaf powder
}

\author{
Author \\ Serina Khatun* \\ University Department of Zoology, T. M. Bhagalpur University, Bhagalpur \\ Email:serina05khatun@gmail.com
}

\begin{abstract}
The results on the effect of oral administration of silk dye waste effluent (2ml/day each animal) on histopathology of the stomach and intestine of swiss albino mice. Revealed sever Histopathological effects in the tissues of both stomach and intestine in Group- II and III but reversible mitigation when using M. oleifera leaves powder at orally fixed dose $(300 \mathrm{mg} / \mathrm{kg} / \mathrm{b} . w /$ day) at 30 days and 60 days incubation period. There is marked atrophy of musculature, disintegration of mucosal epithelial cells characterized by cytoplasmic vacuolization, nuclear pycnosis and nuclear fragmentation. A significant damage in Brunner's gland and crypts of liberkuhn but used of Moringa leafs powder it was significantly recovered the damage tissues has been observed.

Keywords: Silk dye waste effluent, Moringa oleifera leaf powder, histopathology of stomach and intestine, Swiss albino male mice.
\end{abstract}

\section{Introduction}

The human are exposed to various type of environmental contaminants at different stage of their life span, widely held of them are harmful. Silk dye waste is one of the major sources of hazardous pollutants. Industrialization is a godsend of independent India but that is allied with hazardous effluents and discharges polluting the environment. Silk industry as textile provides an important economic stand to the artisans but the dye waste or spent wash arising from the manufacturing unit cause great menace, if released in the open. Silk dye waste effluents are more toxic to environment than the domestic sewage. Bhagalpur $\left(25^{\circ} 17^{\prime} \mathrm{N}\right.$ latitude and $86^{\circ} 83^{\prime}$ Elongit- ude) is endowed with age old silk fabric and yarn production units. Here, the manufacturers use mostly synthetic dye such as azo dyes as colorant for their products. Azo dye forms the largest and most important Silk industry provides an important economic group of synthetic dyes (Mathur et al., 2005).

Moringa oleifera leaf extract is from Moringa oleifera Lamark tree. It is considered one of the world's most useful trees, as almost every part of the tree can be used for food, or has some other beneficial medicinal properties. It is commonly known as 'drumstick' and is being used as antiulcer, diuretic, anti- inflammatory, antimicrobial, potent- antioxidant and wound healing 
agent (Caceres et al., 1991; Udupa et al., 1994; Kurma and Mishra, 1998; Saalu et al., 2011 Bassey et al., 2013), pharmacological properties (Oliveira et al, 1999), it's an exceptional nutritious vegetable (Ram,1994). Its leaves are used as nutrional supplement and growth promoter because of significant presence of protein, selenium, calcium, phosphorus, $\beta$-carotene and $\gamma$ tocopherol in it Nambiar and Seshadri, 2001; Lakshminarayana et al., 2005; Sanchez- Machado et al., 2006).

This study was therefore designed to investigation the effect of Moringa oleifera on silk dye waste effluent induced stomach and intestine in male mice Mus musculus.

\section{Material and Methods}

Animals: - Experiment was performed on 6 to 8 weeks old healthy laboratory inbreed male Mus musculus weighing about 25-30 grams. The animals were obtained from University Department of Zoology, Bhagalpur. Mice were reared and maintained at the animal house of University Dept. of Zoology, T.M.Bhagalpur University, and Bhagalpur under standard conditions and fed with nutritional diet and water.

Collection of Plant material: -Moringa oleifera leaf powder has been procured from own home product (with the help of ECHO Technical Note, By Beth Doerr and Lindsay Cameron, 2005, North Fort Myer, FL 33917, USA) Bhagalpur, Bihar, India.

Collection of silk dye waste:-Silk dye waste effluents were collected directly from discharge point of silk dye industries of Nathnagar, Bhagalpur at regular interval.

Experimental Design: -The mice were divided into 5 groups of 6 animals each. Gr-I (control mice), Gr-II (mice treated with 50\% silk dye waste), Gr-III (mice treated with $100 \%$ silk dye waste), Gr-IV (mice fed with 50\% dye treated with $M$. oleifera leaves powder), Gr-V (mice fed with $100 \%$ dye treated with $M$. oleifera leaves powder).
Dosage:-The control group was given normal food and water. Silk dye wastewas administered orally $2 \mathrm{ml} /$ day (Chaurasia et al, 2005) group II and III for 30 and 60 days duration. M. oleifera leaf powder was also fed orally $300 \mathrm{mg} / \mathrm{kg}$ b.w to both the group IV and V for 30 and 60 days exposure as per the method suggested by Chatterjee et al, 2013.

Biological assays:- Histopathological identification as Stomach and Intestine.

Tissue processing and staining: -After 30 and 60 days of experiment, mice were sacrificed and their organs were removed, were fixed in fixative and paraffinised, Haematoxylin-Eosin stained sections of stomach and intestine were observed under light microscope (Pears, 1985) on 40X magnification.

\section{Results}

Histopathological Observation on Stomach: Histological sections of stomach of control (Gr-I) mice showed normal histoarchitecture (Fig-1). Marked Histopathological changes were observed in the stomach of treated mice (Fig-2\&3). At 30 days treated mice (Gr-II and III) there was significant decrease in the musculature. Both longitudinal and circular muscle layer exhibited atrophy. Significant disintegration of tissues of sub-mucosa and mucosa were observed characterized by presence of irregular masses of tissues with space between them pronounced in 60 days treated mice (Fig-4 \& 5). Mucosa epithelial cells show cytoplasmic vacuolization and pyknotic nuclei.Group-IV and V treated at 30 day incubation period with $M$. oleifera leaf extract significantly increase musculature and both muscle layers were observed recovery (Fig6\&7).Highly significant showed when treated with M. oleifera at 60 days incubation period (Gr-IV and $\mathrm{V}$ ) assimilation of sub-mucosa and mucosa (Fig-8\&9), recovery of villi, longitudinal muscle, decrease cytoplasmic vacuolization and pyknotic nuclei. 


\section{JMSCR Vol||05||Issue||03||Page 19306-19313||March}

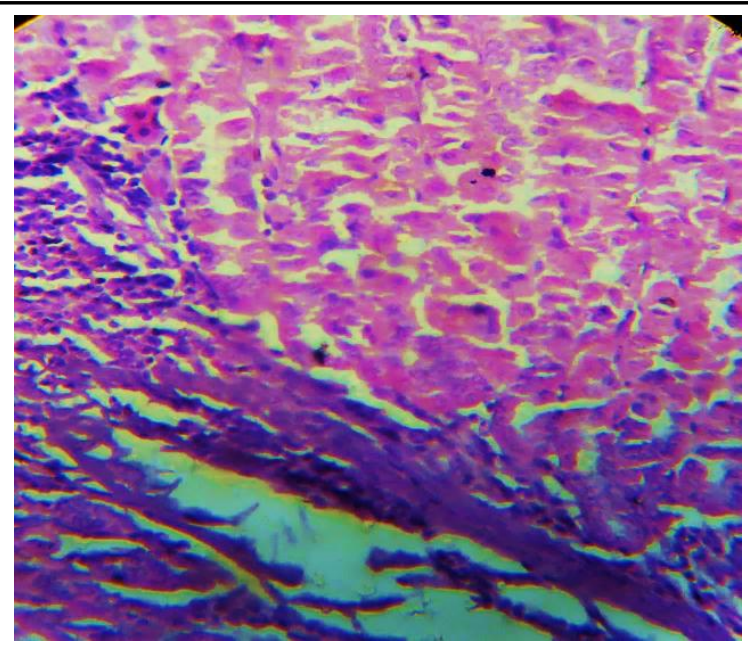

Figure:-1. Showing control groups mice stomach histoarchitecture. (x40, H\&E).

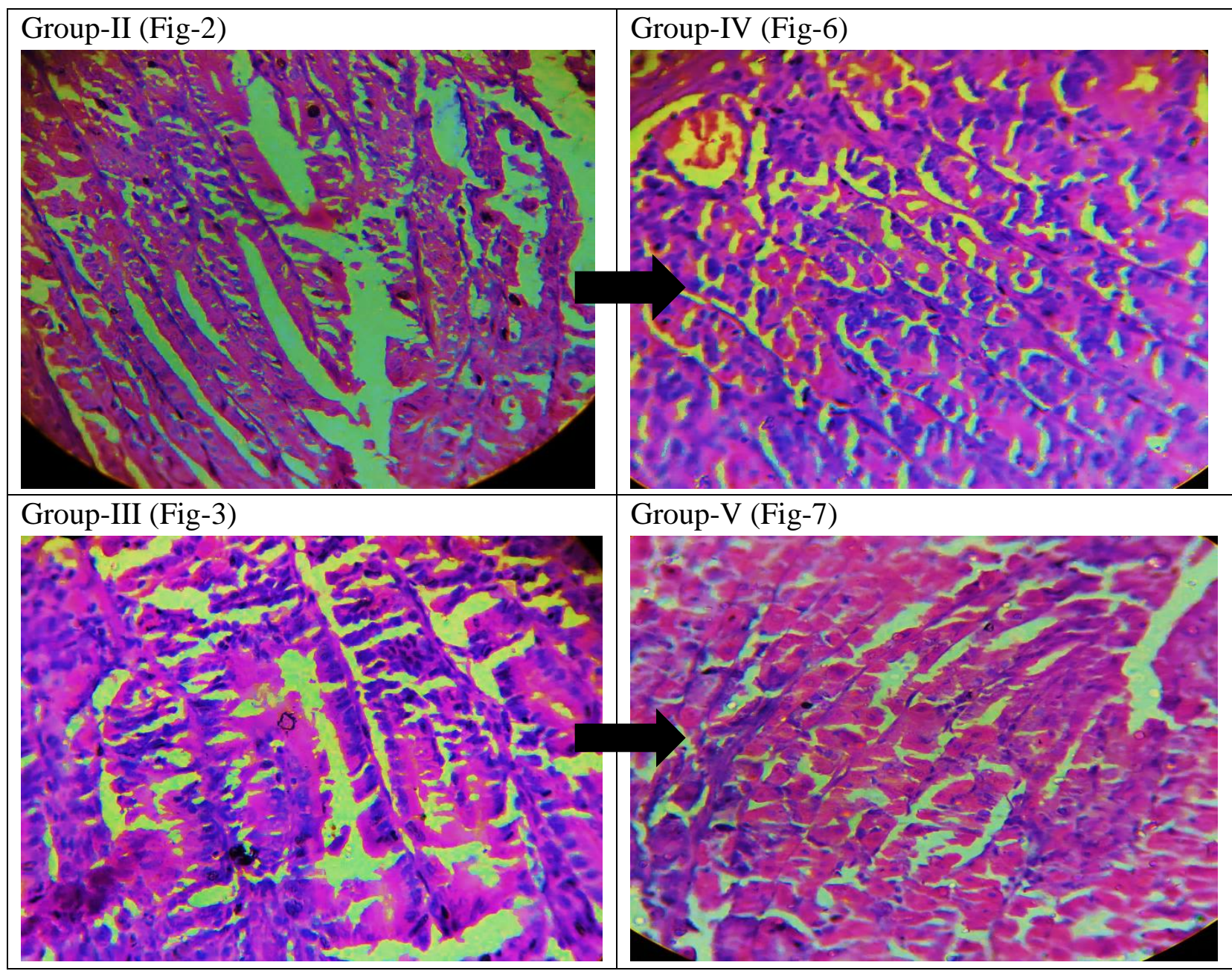

Figure:-2. Treated with 50\% silk dye waste at 30 days incubated stomach. (x40, H\&E).

Figure:-3. Treated with $100 \%$ silk dye waste at 30 days incubated stomach. (x40, H\&E).

Figure:-6. 50\% silk dye waste effluent fed with M. oleifera leaf extract at 30 days incubated stomach. (x40, $\mathrm{H} \& \mathrm{E})$.

Figure:-7. $100 \%$ silk dye waste effluent fed with M. oleifera leaf extract at 30 days incubated stomach. (x40, H\&E). 


\section{JMSCR Vol||05||Issue||03||Page 19306-19313||March}

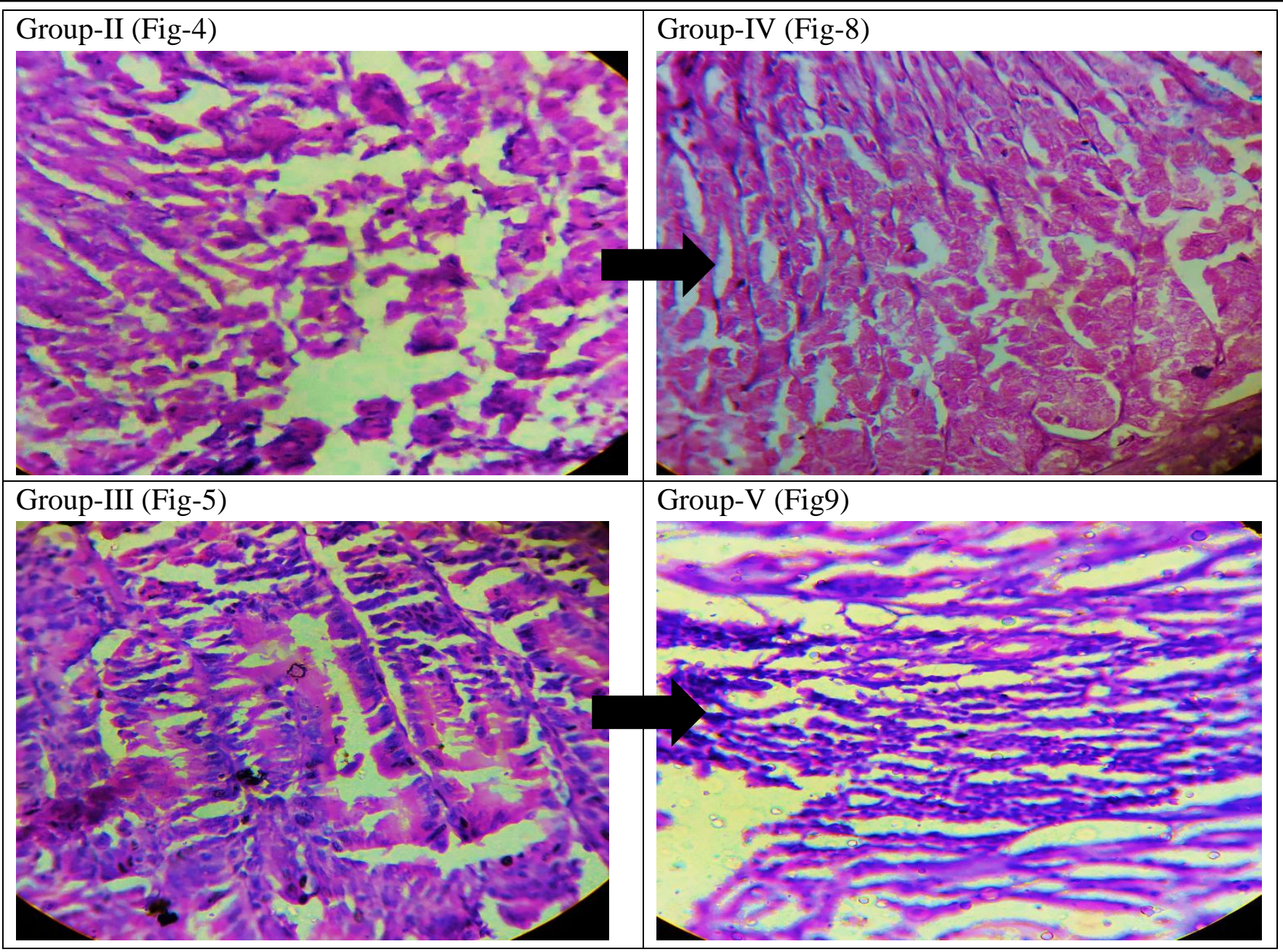

Figure:-4. Treated with 50\% silk dye waste at 60 days incubated stomach. (x40, H\&E).

Figure:-5. Treated with $100 \%$ silk dye waste at 60 days incubated stomach. (x40, H\&E).

Figure:-8. 50\% silk dye waste effluent fed with M. oleifera leaf extract at 60 days incubated stomach. (x40, $\mathrm{H} \& \mathrm{E})$.

Figure:-9. 100\% silk dye waste effluent fed with M. oleifera leaf extract at 60 days incubated stomach. (x40, H\&E).

\section{Histopathological Observation on Intestine}

The intestine of untreated mice has normal intestinal histoarchitecture (Fig-10). The mucosa forms a series finger like villi, a core of lamina propria, blood capillaries. Sever histological changes as atrophy of musculaturewasobserved in silk dye treated mice at 30 days incubation period (Gr-II and III). At many places serosa is disrupted and separated from musculature, areolar connective tissue of the sub-mucosa and mucosa showed atrophy (Fig-11\&12). At 60 day incubation period (Gr-II and III) were observed irregular masses of tissues, separated by small to large irregular spaces and paler staining. Distortion of villi was prominent in both categories of treated mice. Absorptive, goblet, enter endocrine and paneth cells of columnar epithelium including cells was disrupted leading to formation of numerous vacuoles (Fig-13\&14). Group-IV and V treated at 30 days incubation period with $M$. oleifera leaf extract were observed significant recovery of damage musculature, both connective tissues and blood capillary (Fig15\&16). Highly significant showed when treated with $M$. oleifera extract at 60 days incubation period (Gr-IV and V) incorporation of symmetrical masses of tissues, finger like villi and appear simple columnar mucosal epithelium contains absorptive goblet (Fig-17\&18). 


\section{JMSCR Vol||05||Issue||03||Page 19306-19313||March}

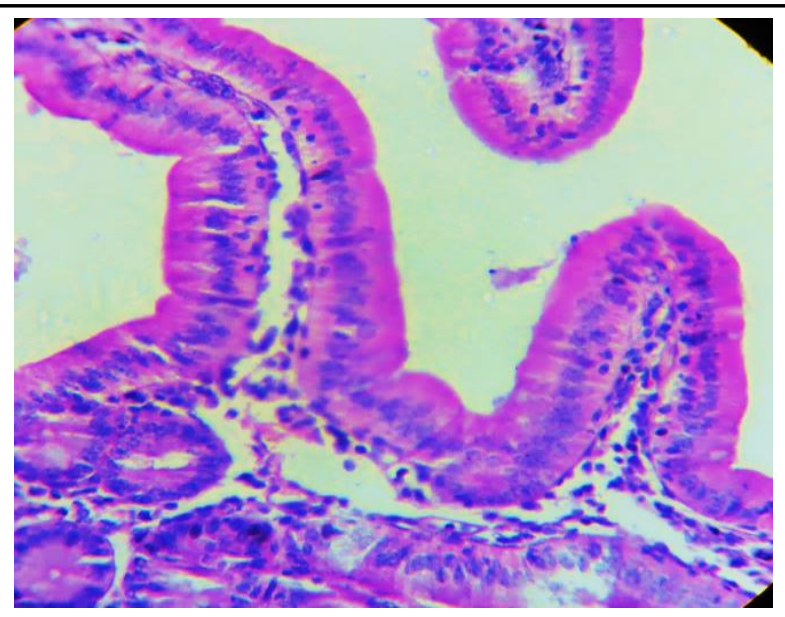

Figure:-10. Intestine of mice in control (Group-I) showing normal histoarchitecture (x40, H\&E).

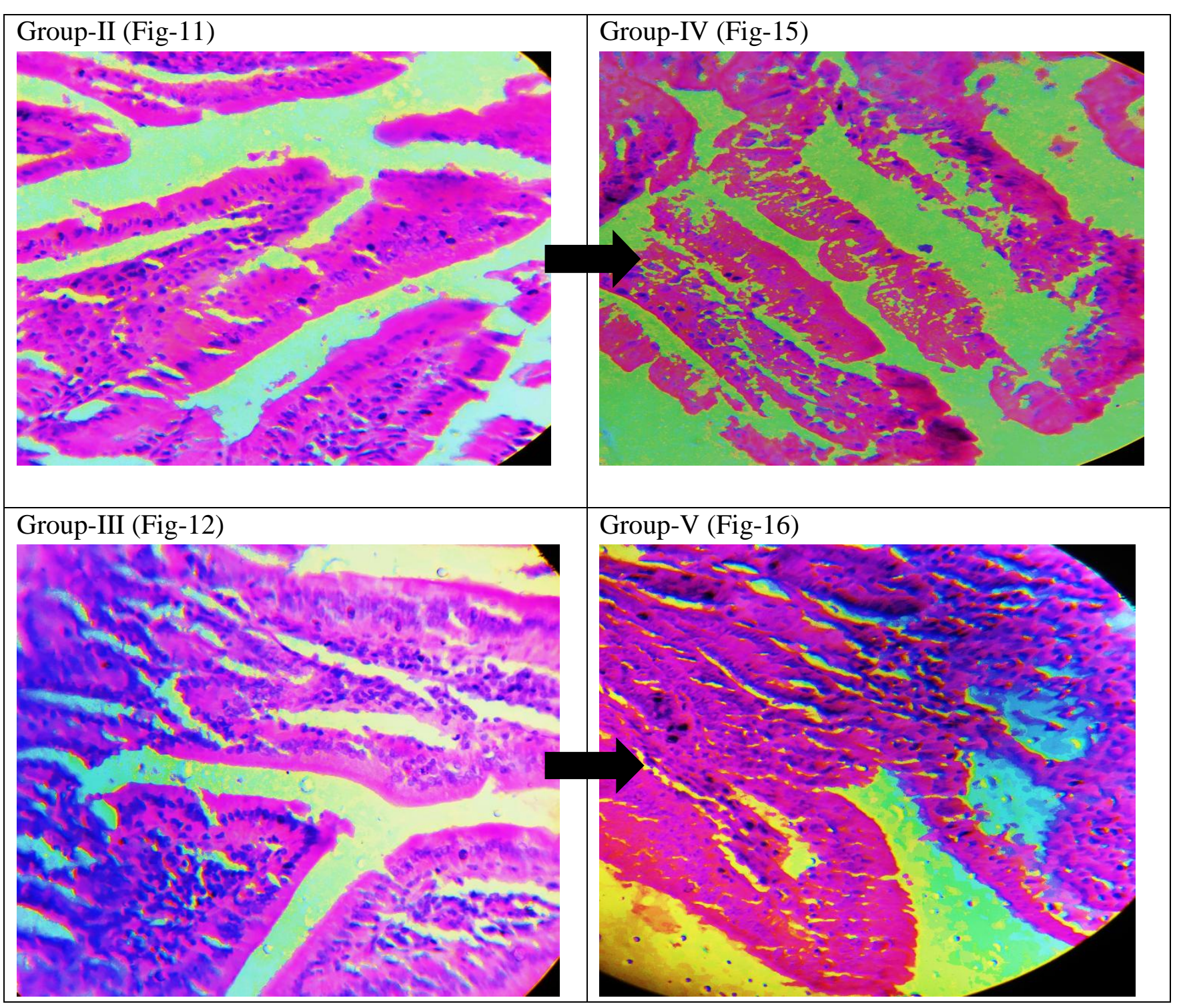

Figure: -11. 50\% silk dye waste effluent induced intestine.(x40, H\&E).

Figure:-12. 100\% silk dye waste effluent fed at 30 days incubated mice intestine. (x40, H\&E).

Figure: -15. 50\% silk dye waste effluent fed with M. oleifera leaf extract at 30 days incubated mice intestine. (x40, H\&E).

Figure:-16. 100\% silk dye waste fed with M. oleifera leaf extract at 30 day incubated mice intestine. (x40, $\mathrm{H} \& \mathrm{E})$. 


\section{JMSCR VoI||05||Issue||03||Page 19306-19313||March}

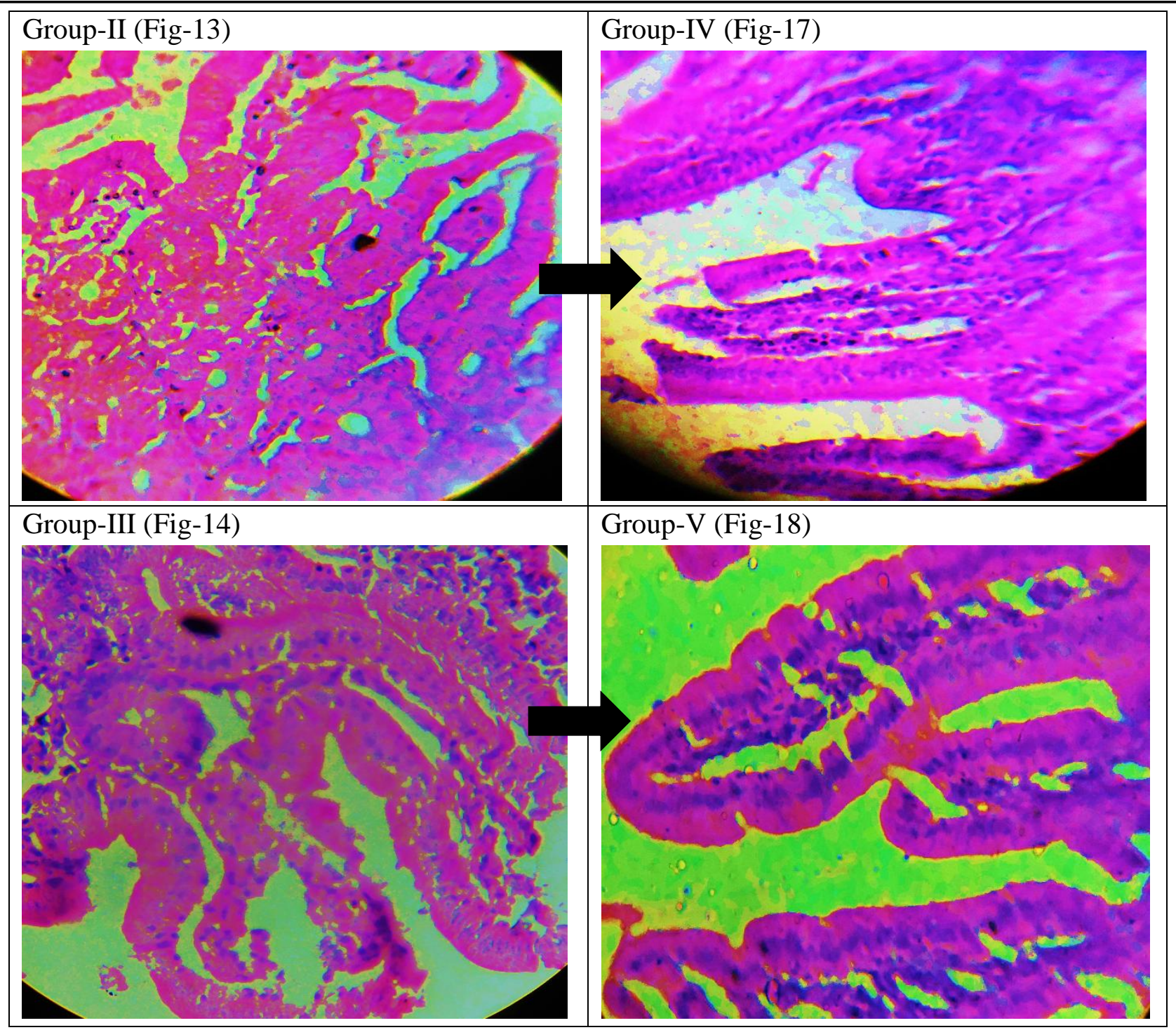

Figure:-13. Treated with 50\% silk dye waste at 60 day incubated mice intestine. (x40, H\&E).

Figure:-14.Treated with $100 \%$ silk dye waste at 60 day incubated mice intestine. (x40, H\&E).

Figure:-17. 50\% silk dye waste effluent induced mice fed $M$. oleifera leaf extract at 60 day incubated intestine. (x40, H\&E).

Figure:-18. $100 \%$ silk dye waste effluent induced mice fed M. oleifera leaf extract at 60 days incubated intestine. (x40, H\&E).

\section{Discussion}

In the present experimental study were investigated, the histopathological effects of silk dye waste effluent on mice stomach and intestine and their significant mitigation using Moringa oleifera leaf extract. The histopathological alteration induced by different heavy metals toxicity (Kwon et al, 1997; Bataineh et al, 1998; Mayyas et al, 2005; Yang et al, 2006 and Garba et al, 2007). The effects of $\mathrm{CdCl}_{2}$ on the stomach, testis, kidney, renal organ and liver have been reported by (Saksena and Lau 1979; Bataineh et al, 1998; Karmaker et al, 2000; Garba et al, 2007). Mechanism for the cytoplasmic vacuolization has been given by Robbin and Angell (1976) as one of the important responses to all forms of cell injury. Disturbances in lipid inclusions and fat metabolism in response to toxic substances result in cytoplasmic vacuolization (Zhang and Wang, 1984). These findings agree with those of Maher et al (2007) who informed that melittin at low concentrations did not induced any cytotoxicity in the intestinal tissue of rats and did not affect their cellular functions such as mucus secretion. Long 
term melittin treatment resulted in a loss of microvilli, an increase in cell debris and destruction of intestinal tight junctions and cellcell adhesion (Tosteson et al, 1985). In intestinal enterocytes and goblet cells, melittin led to a reduction in cell viability associated with necrotic cell death, and increase mucus secretion (Maher et al, 2007; Maher and McClean, 2008). These aspects of melittin activity and its ability to disrupt the integrity of the cell membrane may be involved in the peptide cytotoxicity which is considered as a limiting factor in the use of melittin in infectious disease (Maher and McClean, 2006).Prakash et al (2010) added that SMA is related to the contractile and the cytoskeletal functions in various types of cells, where it severs to facilitate cell contraction and migration.Moringa oleifera leaf extract act on toxicity impact of silk dye as biochemical and haematological (Serina et al, 1016) and reproductive disability (Khatun et al, 2017).The flower bud of Moringa widely consumed has been reported to possess antiulcer activity against aspirin-induced ulcer in rats (Aktar and Ahmad, 1995). A clinical study from the University of Calcutta shows that Moringa oleifera protects against ulcer formation. The high fiber content facilities easy movement of stomach and intestine contents along the digestive tract and relieves constipation. Moringa can take care of minor digestive problems caused by gastrointestinal worms and microbes. The root extract is an herbal remedy for helminth worms (Sierra, 2016). Dvorak (2007) reported that Moringa seed powder $(250$ and $500 \mathrm{mg} / \mathrm{kg}$ ) with arsenic significantly increased the activities of SOD, catalase in stomach and intestine. Moringa oleifera powder increases the actives of epithelial cells, blood capillaries, villi, musculature layer and Brunner's glands (Goodman et al,1993; Caceres et al, 2014; Bassey et al, 2016).

On the basis of above discussed histopathological observations and facts it can be concluded that the M. oleifera leaf powder significantly reduce the alteration arisen in damage of Stomach, Intestine and associated structures in the toxicity impact of silk dyes waste effluent induced male mice.

\section{References}

1. Bataineh, H; Al-Hammod, $\mathrm{M}$. and Elbetieha, A. (1998): Assessment of aggression, sexual behaviour and fertility in adult male rat following long- term ingestion of four industrial metal salts. J. Human. Exp. Toxicol, 17:57-576.

2. Caceres A, Cabrera O, Morales O, Mollinedo P, Mendia P, 1991. Pharmacological properties of $\mathrm{M}$. oleifera. 1: preminary screening for antimicrobial activity. Journal of Ethnopharmacology, 33(3):213-216.

3. Garba, S.H; Adelaiye, A.B. and Mshelia, L.Y. (2007): Toxicological effects of Inhaled Mosquito Coil Smoke on the rat spleen: A haematological and histological study. J. Med. Sci, 7(1):94-99.

4. Karmaker, R; Bhattacharya, R. and Chatterjee, M (2000): Biochemical, haematological and Histopathological study in relation to time-related cadmium induced hepatotoxicity in mice. Biometal, 13:231-239.

5. Khatun, S. and Varma, M.C. (2017): Toxicity impact of silk dye waste effluent on biochemical estimation of swiss albino male mice Mus musculus and mitigation M. oleifera leaf extract. World. J. of Pharmacy and Pharmaceutic Sciences, 6(1):1621-1629.

6. Kumar NA and Pari L.2003. Antioxidant Action of Moringa oleifera Lam. against peroxidation in rats. $\mathrm{J}$ Med Food, 6(3):255-259.

7. Kwon, K.S; Cho, K.J. and Yang, E.J. (1997): The study of anatomical and biochemical effects of silk dye on the testis in rats. Dev. Reprod, 1:125-132.

8. Lakshminarayana R, Raju M, Krishnakantha TP, Baskaran V, 2005. Determination of major carotenoids in a 
few Indian leafy vegetables by highperformance liquid chromatography. Journal of Agricultural and Food Chemistry, 53(8):2838-2842.

9. Maher, S; Feighery, L; Brayden, D. and Mcclean, S (2007): Melittin as a permeability enhancer II: in vitro investigations in human mucus secreting intestinal monolayers and rat colonic mucosa. Pharm.Res, 24(7):1346-1356.

10. Maher, S. and McClean, S (2006): Investigation of the cytotoxicity of eukaryotic and prokaryotic antimicrobial peptides in intestinal epithelial cell in vitro. Biochem. Pharmacol, 71(9):12891298.

11. Maher, S. and McClean, S. (2008): Melittin exhibits necrotic cytotoxicity in gastrointestinal cells which is attenuated by cholesterol. Biochem. Pharmacol, 75(5):1104-1114.

12. Mayyas, I; Elbetieha, A; Khamas, W. and Khamas, W.A (2005): Evalution of reproductive and fertility toxic potentials of aluminium chloride on adult male mice. J. Anim. Vet. Adv, 4:224-233.

13. Prakash, S; LeMaire, S; Guo, D; Russell, L; Regalado, E; Golabbakhas, H. and Estrera, A (2010): Rare copy number variants disrupt genes regulating vascular smooth muscle cell adhesion and contractility in sporadic thoracic aortic aneurysms and dissections. Am. J. Hum. Genet, 87(6):743-756.

14. Robbins, S. and Angell, D (1976): Basic pathology, $2^{\text {nd }}$ Ed, W.B. Saunders Company, Philadelphia, London.

15. Saksena, S. and Lau, I (1979): Effect of cadmium chloride on testicular steroidogenesis and fertility of male rats. J. Endocrinol, 74:6-12.

16. Serina, k; Varma, M. C (2016): Effect of M. oleifera leaf extract on silk dye effluent affected haematological and biochemical parameter on Swiss albino male mice. Amer. Inter. J. Form, Appli and Natu. Sci, 14(1), pp.50-55.

17. Tosteson, M.T; Holmes, S.J; Razin, M. and Tosteson, D.C. (1985): Melittin lysis of red cells. J. Membr. Biol, 87(1):35-44.

18. Udupa SL, Udupa AL,Kulkrni DR, 1994.Study on the anti-inflammatory and healing properties of M. oleifera and marmelos. Fitoterapia, 65(2):119-123.

19. Yang, H.S; Dong Kein, H; Jung Rana, K. and Jae Chul Sim (2006): Effects of $\alpha$ tocopherol on silk dye induced toxicity in rat testis and spermatogenesis. Journal of Koream Medical Science. 21(3):445-451.

20. Zhang, L.Y. and Wang, C.X (1984): Histopathological and Histochemical studies on toxic effect of brodifacoum in mouse liver. Acta Acad Med Sci, 6(5):386388. 